\title{
Clostridium straminisolvens sp. nov., a moderately thermophilic, aerotolerant and cellulolytic bacterium isolated from a cellulose-degrading bacterial community
}

\author{
Souichiro Kato, ${ }^{1}$ Shin Haruta, ${ }^{1}$ Zong Jun Cui, ${ }^{1}$ Masaharu Ishii, ${ }^{1}$ \\ Akira Yokota ${ }^{2}$ and Yasuo Igarashi ${ }^{1}$ \\ ${ }^{1}$ Department of Biotechnology, Graduate School of Agricultural and Life Sciences, University of \\ Tokyo, Yayoi 1-1-1, Bunkyo-ku, Tokyo 113-8657, Japan \\ ${ }^{2}$ Laboratory of Bioresources, Institute of Molecular and Cellular Biosciences, University of \\ Tokyo, Yayoi 1-1-1, Bunkyo-ku, Tokyo 113-8657, Japan
}

Correspondence

Yasuo Igarashi

aigara@mail.ecc.u-tokyo.ac.jp
Cellulosic materials are among the Earth's most abundant, renewable resources, and their degradation and utilization by microbes are considered very important (Coughlan \& Mayer, 1992). Micro-organisms that degrade cellulosic materials, and the enzymes involved (e.g. cellulase, xylanase and peroxidase), have been well studied (Fukumori et al., 1989; Hayashi et al., 1999) and several microbial-related applications have been developed for textile, food and paper-pulp processing. However, utilizing these microorganisms and enzymes to process natural cellulosic materials without pre-treatment and/or sterilization is difficult. In nature, cellulosic materials are degraded by the cooperation of many micro-organisms. It has been reported that a mixed culture comprising a cellulolytic bacterium and a non-cellulolytic bacterium is ideal for degrading cellulose (Odom \& Wall 1983; Lewis et al., 1988).

In our laboratory, a bacterial community capable of effectively degrading various cellulosic materials (e.g. filter paper, cotton and rice straw) under aerobic static conditions was constructed by means of a succession of enrichment cultures, as reported in Haruta et al. (2002).

Published online ahead of print on 7 May 2004 as DOI 10.1099/ ijs.0.63148-0.

The GenBank/EMBL/DDBJ accession number for the 16S rRNA gene sequence of strain $C S K 1^{\top}$ is $A B 125279$.
This bacterial community degraded natural cellulosic materials without sterilization and had a high degree of stability (the cellulose-degrading efficiency and the composition of the bacteria did not change after more than 20 subcultures). Denaturing gradient gel electrophoresis and $16 \mathrm{~S}$ rRNA gene sequence analyses indicated the coexistence of aerobic and anaerobic bacteria in the community. Elucidation of the characteristics of each bacterium in the community (especially the cellulolytic bacteria) will lead to greater knowledge of the mechanisms of effective cellulose degradation by cooperation amongst bacteria.

In this article, we report the isolation of a novel strain, $\mathrm{CSK}^{\mathrm{T}}$, from a cellulose-degrading bacterial community. We characterized this strain further as a novel moderately thermophilic, cellulolytic member of cluster III of the genus Clostridium. We propose to assign this bacterium to a novel species of the genus Clostridium, namely Clostridium straminisolvens sp. nov.

Unless stated otherwise, stringent anaerobic procedures (Holdeman et al., 1977) were used for culturing and for physiological and substrate-utilization tests. All anaerobic media containing reducing agents were pre-reduced by cooling after sterilization inside an anaerobic chamber operated with anaerobic gas mixture $\left(\mathrm{H}_{2} / \mathrm{N}_{2}: 10: 90, \mathrm{v} / \mathrm{v}\right)$. Only fully reduced media, as indicated by the colourless state of resazurin in the media, were used for cultivation. 
The isolation source was the cellulose-degrading bacterial community (Haruta et al., 2002) that was cultured in liquid medium containing the following (per litre distilled water): yeast extract, $1 \mathrm{~g}$; peptone, $5 \mathrm{~g}$; $\mathrm{CaCO}_{3}, 2 \mathrm{~g}$; $\mathrm{NaCl}, 5 \mathrm{~g}$; dried rice straw, $10 \mathrm{~g}$, under static conditions at $50{ }^{\circ} \mathrm{C}$. After rice-straw degradation had been observed, the rice straw was removed and washed four times with anaerobic buffer (PBS with 1\%, w/v, L-cysteine hydrochloride) under anaerobic conditions. The washed rice straw was inoculated into isolation medium (Drent et al., 1991) containing the following (per litre distilled water): $\mathrm{NaCl}, 1 \cdot 2 \mathrm{~g} ; \mathrm{MgCl}_{2} \cdot 6 \mathrm{H}_{2} \mathrm{O}$, $0.4 \mathrm{~g} ; \mathrm{KCl}, 0.3 \mathrm{~g} ; \mathrm{CaCl}_{2} .2 \mathrm{H}_{2} \mathrm{O}, 0.15 \mathrm{~g} ; \mathrm{NH}_{4} \mathrm{Cl}, 0.27 \mathrm{~g}$; $\mathrm{KH}_{2} \mathrm{PO}_{4}, 0.205 \mathrm{~g} ; \mathrm{Na}_{2} \mathrm{SO}_{4}, 0.1 \mathrm{~g} ; \mathrm{NaHCO}_{3}, 2.52 \mathrm{~g}$; $\mathrm{Na}_{2} \mathrm{~S} .9 \mathrm{H}_{2} \mathrm{O}, 0 \cdot 15 \mathrm{~g}$; yeast extract, $25 \mathrm{mg}$; Casamino acids, $25 \mathrm{mg}$; filter paper (Advantec quantitative filter paper no. 5A) or ball-milled cellulose [Avicel (Merck), ball-milled for 1 min with a TI-200 vibrating sample mill (CMT)], $10 \mathrm{~g}$; resazurin, $1 \mathrm{mg}$; trace-element solution SI $6^{+}$[containing (per litre distilled water): $\mathrm{FeCl}_{2} .4 \mathrm{H}_{2} \mathrm{O}, 1.5 \mathrm{~g} ; \mathrm{ZnCl}_{2}, 70 \mathrm{mg}$; $\mathrm{MnCl}_{2} .4 \mathrm{H}_{2} \mathrm{O}, 100 \mathrm{mg} ; \mathrm{H}_{3} \mathrm{BO}_{3}, 6 \mathrm{mg} ; \mathrm{CoCl}_{2} \cdot 6 \mathrm{H}_{2} \mathrm{O}, 190 \mathrm{mg}$; $\mathrm{CuCl}_{2} \cdot 2 \mathrm{H}_{2} \mathrm{O}, 2 \mathrm{mg} ; \mathrm{NiCl}_{2} \cdot 6 \mathrm{H}_{2} \mathrm{O}, 24 \mathrm{mg} ; \mathrm{Na}_{2} \mathrm{MoO}_{4} \cdot 2 \mathrm{H}_{2} \mathrm{O}$, $36 \mathrm{mg}$ ], $1 \mathrm{ml}$; and vitamin solution, $1 \mathrm{ml}$ (Heijthuijsen \& Hansen, 1986).

Growth experiments were performed in duplicate, using medium 122 [Saddler \& Chan, 1982, and DSMZ List of Media (http://www.dsmz.de/media/med122.htm)] containing the following (per litre distilled water): $\left(\mathrm{NH}_{4}\right)_{2} \mathrm{SO}_{4}$, $1.3 \mathrm{~g} ; \mathrm{MgCl}_{2} \cdot 6 \mathrm{H}_{2} \mathrm{O}, 2 \cdot 6 \mathrm{~g} ; \mathrm{KH}_{2} \mathrm{PO}_{4}, 1 \cdot 43 \mathrm{~g} ; \mathrm{K}_{2} \mathrm{HPO}_{4} \cdot 3 \mathrm{H}_{2} \mathrm{O}$, $7 \cdot 2 \mathrm{~g} ; \mathrm{CaCl}_{2} .6 \mathrm{H}_{2} \mathrm{O}, 0 \cdot 13 \mathrm{~g} ; \mathrm{FeSO}_{4} .7 \mathrm{H}_{2} \mathrm{O}, 1 \cdot 1 \mathrm{mg}$; sodium $\beta$-glycerophosphate, $6.0 \mathrm{~g}$; yeast extract, $4.5 \mathrm{~g}$; filter paper, ball-milled cellulose or cellobiose, $10 \mathrm{~g}$; glutathione (reduced), $0.25 \mathrm{~g}$; and resazurin, $1 \mathrm{mg}$. The potential for growth and cellulose degradation at various initial $\mathrm{pH}$ values ranging from $5 \cdot 0$ to $8 \cdot 0$ (adjusted by addition of $1 \mathrm{M}$ $\mathrm{HCl}$ or $1 \mathrm{M} \mathrm{NaOH}$ ) was determined using medium 122 with cellobiose $(0.5 \%, \mathrm{w} / \mathrm{v})$ or filter paper $(1 \%, \mathrm{w} / \mathrm{v})$ at $50{ }^{\circ} \mathrm{C}$. The potential for growth and cellulose degradation at various temperatures ranging from 37 to $70^{\circ} \mathrm{C}$ was determined using medium 122 with cellobiose $(0.5 \%$, $\mathrm{w} / \mathrm{v})$ or filter paper $(1 \%, \mathrm{w} / \mathrm{v})$ at $\mathrm{pH} 7 \cdot 0$. The cellulosic substrate degradation rates were determined using medium 122 with filter paper or rice straw $(1 \%, w / v)$ at $50{ }^{\circ} \mathrm{C}$, $\mathrm{pH} 7 \cdot 0$. Residual solid cellulosic materials were gravimetrically determined using a method described by Taillisz et al. (1989), with uninoculated medium as a negative control. Individual substrate utilization was assessed at $50{ }^{\circ} \mathrm{C}(\mathrm{pH} 7 \cdot 0)$ using medium 122 containing each substrate $(0.5 \%, \mathrm{w} / \mathrm{v})$. The substrates tested were glucose, fructose, ribose, mannose, mannitol, melibiose, saccharose, xylose, cellobiose, sucrose, lactose, ball-milled cellulose, filter paper, rice straw, xylan (from beechwood; Sigma), starch (from potato; Kanto Chemical), laminarin (from Laminaria digitata; Sigma), pachyman (from Poria cocos; ICN Biomedicals), chitin, chitosan (from crab shells; Sigma) and 1,3- $\beta$-glucan. Utilization of a substrate was judged from the $\mathrm{pH}$ drop of the culture solution after 5 days cultivation. Motility, aesculin hydrolysis, nitrate reduction, casein digestion, lectinase activity, lipase activity and indole production were tested using methods described by Holdeman et al. (1977). The microscopic sample for checking motility was prepared in an anaerobic chamber. Fermentation products were determined for strain $\mathrm{CSK} 1^{\mathrm{T}}$ grown in medium 122 with ball-milled cellulose $(1 \%$, w/v) or cellobiose $(0.5 \%, \mathrm{w} / \mathrm{v})$ at $50{ }^{\circ} \mathrm{C}$ for 5 days. Production of $\mathrm{H}_{2}$ and $\mathrm{CO}_{2}$ were determined by GC (Küsel \& Drake, 1995). Organic acid and alcohol by-products were determined by HPLC (Tanaka et al., 2002). The potential for growth and cellulose degradation of strain $\mathrm{CSK}^{\mathrm{T}}$ and Clostridium thermocellum IAM $13660^{\mathrm{T}}$ under the gas phase with various concentrations of $\mathrm{O}_{2}(0,1,2,4$ and $8 \%, \mathrm{v} / \mathrm{v})$ was determined using medium 122 with ballmilled cellulose $(1 \%, \mathrm{w} / \mathrm{v})$ or cellobiose $(0.5 \%, \mathrm{w} / \mathrm{v})$ at $50{ }^{\circ} \mathrm{C}$ (for strain $\mathrm{CSK} 1^{\mathrm{T}}$ ) or $60^{\circ} \mathrm{C}$ (for C. thermocellum). The gas phase was replaced with a gas mix of $\mathrm{N}_{2}$ and $\mathrm{O}_{2}$, prepared in appropriate ratios by using a GB-4C gas blender (Kofloc). Growth was judged from the $\mathrm{pH}$ drop of the culture solution after 5 days cultivation.

DNA was extracted by using benzyl chloride methodology (Zhu et al., 1993). The DNA G +C composition of strain $\mathrm{CSK}_{1}^{\mathrm{T}}$ was determined by HPLC (Mesbah et al., 1989). DNA-DNA hybridization was performed by incubating target DNA with biotinylated DNA for $2 \mathrm{~h}$ at $45^{\circ} \mathrm{C}$ in microdilution wells; the amount of hybridization was assessed fluorometrically (Ezaki et al., 1989). Genomic DNA from Escherichia coli was used as the negative control.

The 16S rRNA gene sequence of strain $\mathrm{CSK}^{\mathrm{T}}$ was determined by direct sequencing of the purified PCR-amplified $16 \mathrm{~S}$ rRNA gene fragment. Genomic DNA was used as the PCR template. The PCR was performed with universal bacterial primers complementary to conserved regions of the $5^{\prime}$ and $3^{\prime}$ ends of the $16 \mathrm{~S}$ rRNA gene. The primer sequences were 27F (forward; $5^{\prime}$-AGAGTTTGATCCTGGCTCAG-3' ${ }^{\prime}$, positions 8-27 in E. coli numbering) and 1512R (reverse; 5'-ACGGCTACCTTGTTACGACT-3', positions 1512-1493 in E. coli numbering) (Devereux \& Willis, 1995). The PCR was performed using AmpliTaqGold (Perkin Elmer). After initial denaturation for $10 \mathrm{~min}$ at $95^{\circ} \mathrm{C}$, target DNA was amplified for 30 cycles. Each cycle consisted of denaturation for $30 \mathrm{~s}$ at $93^{\circ} \mathrm{C}$, annealing for $30 \mathrm{~s}$ at $55^{\circ} \mathrm{C}$ and extension for $2 \mathrm{~min}$ at $72^{\circ} \mathrm{C}$. The final extension was for $5 \mathrm{~min}$ at $72^{\circ} \mathrm{C}$. The PCR products were purified with the QIAquick PCR purification kit (Qiagen) according to the manufacturer's instructions. The purified 16S rRNA gene was sequenced directly using the ABI PRISM BigDye Terminator cycle sequencing ready reaction kit and an ABI PRISM model 377 genetic analyser (Perkin Elmer). The 16S rRNA gene sequence of strain $\mathrm{CSK} 1^{\mathrm{T}}$ was compared with those from the DDBJ nucleotide sequence database, using BLAST (Altschul et al., 1997). To determine the phylogenetic position of the isolate, its sequence and the sequences of its close relatives in the Clostridium subphylum were aligned using the program CLUSTAL_X (version 1.81) (Thompson et al., 1997). A phylogenetic tree was constructed using the 
neighbour-joining method (Saitou \& Nei, 1987) with the program MEGA (version 2.1) (Kumar et al., 2001). To evaluate the robustness of the inferred tree, the bootstrap resampling method of Felsenstein (1985) was used, with 1000 replicates.

The bacteria were enriched in batch culture under static conditions using screw-capped test tubes $(16 \times 100 \mathrm{~mm})$ filled with $5 \mathrm{ml}$ isolation medium and ball-milled cellulose $\left(1 \mathrm{~g}^{-1}\right)$ under anaerobic conditions using an AnaeroPack pouch bag (Mitsubishi Gas Chemical) with an AnaeroPack oxygen absorber at $50{ }^{\circ} \mathrm{C}$. After $4-5$ days cultivation, the colour of the ball-milled cellulose became yellow, indicating that degradation was progressing. Bacteria adhering to the cellulose powder were collected by centrifugation (approx. $300 \mathrm{~g}$ for $5 \mathrm{~min}$ ) and transferred into fresh medium. This enrichment culturing procedure was repeated more than five times. The enriched bacteria were streaked on a sterilized filter paper moistened with anaerobic buffer, covered with isolation medium containing $1.5 \%(\mathrm{w} / \mathrm{v})$ agar (without carbohydrates) and then incubated under anaerobic conditions (using the AnaeroPack system) at $50{ }^{\circ} \mathrm{C}$. After $4-5$ days cultivation, yellow-coloured colonies appeared on the filter paper. After the colonizing procedures had been repeated, confirmation of the purity of strain $\mathrm{CSK}_{1}^{\mathrm{T}}$ was achieved by microscopic observation.

Cells of strain $\mathrm{CSK}^{\mathrm{T}}$ were observed, under a phasecontrast microscope (Axioplan II imaging; Carl Zeiss) (Fig. 1), to be straight or slightly curved rods, $0 \cdot 5-1 \cdot 0 \mu \mathrm{m}$ wide and $3 \cdot 0-8 \cdot 0 \mu \mathrm{m}$ long. Spores were oval, subterminal and $0 \cdot 5-1 \cdot 0 \times 1 \cdot 0-1 \cdot 5 \mu \mathrm{m}$. Colonies grown in cellobiose agar medium were tan-yellow, round, entire and 1.0 $2 \cdot 0 \mathrm{~mm}$ in diameter.

Strain CSK1 ${ }^{\mathrm{T}}$ grew and degraded cellulose (filter paper and ball-milled cellulose) at temperatures ranging from 50 to $60^{\circ} \mathrm{C}$, with an optimum temperature range of $50-55^{\circ} \mathrm{C}$. For strain $\mathrm{CSK} 1^{\mathrm{T}}$, the optimum $\mathrm{pH}$ for growth and cellulose degradation was $7 \cdot 5$; growth and cellulose degradation occurred between $\mathrm{pH} 6 \cdot 0$ and $8 \cdot 5$. Older cultures of strain $\mathrm{CSK}^{\mathrm{T}}$ show extensive growth in the culture liquid phase, as does C. thermocellum. Strain $\mathrm{CSK}^{\mathrm{T}}$ did not grow in medium 122 without carbohydrates. Cellobiose, laminarin and cellulosic materials (ball-milled cellulose, filter paper

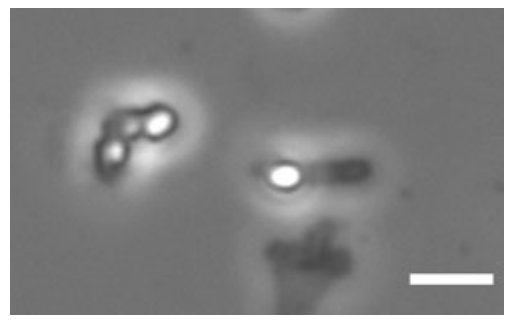

Fig. 1. Phase-contrast micrograph of cells of strain $\mathrm{CSK} 1^{\top}$, showing subterminal oval spores. Bar, $5 \mu \mathrm{m}$. and rice straw) were each utilized as sole carbon and energy sources by strain $\mathrm{CSK}^{\mathrm{T}}$ in medium 122 . Other substrates tested were not fermented. Motility was not observed, even under anaerobic conditions. Aesculin was hydrolysed. The following biochemical properties were tested and produced negative results: nitrate reduction, casein digestion, lectinase activity, lipase activity and indole production. In medium 122 with cellobiose or ball-milled cellulose, the major fermentation products formed by strain $\mathrm{CSK}_{1}{ }^{\mathrm{T}}$ were acetate, ethanol, hydrogen and carbon dioxide; minor amounts of lactate were detected.

Strain $\mathrm{CSK}^{\mathrm{T}}$ degraded filter paper $(62 \%)$ and rice straw ( $45 \%$, on a dry organic matter basis) after 8 days cultivation. The degradation rates (especially for rice straw) were apparently lower than those of the original bacterial community, which degrades more than $80 \%$ of rice straw within 8 days (Haruta et al., 2002). In the bacterial community, non-cellulolytic bacteria would help strain $\mathrm{CSK}_{1}{ }^{\mathrm{T}}$ degrade cellulosic materials more completely.

The 16S rRNA gene sequence of strain $\mathrm{CSK}^{\mathrm{T}}$, containing a continuous stretch of $1451 \mathrm{nt}$ (approx. positions 29-1492 according to E. coli numbering), was compared with those from the DDBJ nucleotide sequence database. The results of the sequence-similarity calculations indicated that the relatives of strain $\mathrm{CSK}^{\mathrm{T}}$ are C. thermocellum DSM $1237^{\mathrm{T}}$ $(96 \cdot 2 \%)$ and Clostridium aldrichii DSM $6159^{\mathrm{T}}(95 \cdot 1 \%)$. These relatives are reported as being anaerobic, cellulolytic bacteria (Ng et al., 1977; Yang et al., 1990). The phylogenetic tree was constructed using the neighbour-joining method; it indicates that strain CSK ${ }^{\mathrm{T}}$ belongs to cluster III (Collins et al., 1994) of the genus Clostridium (Fig. 2).

DNA-DNA hybridization experiments revealed a $23 \%$ genome sequence similarity between strain $\mathrm{CSK}^{\mathrm{T}}$ and $C$. thermocellum IAM $13660^{\mathrm{T}}$ when genomic DNA from E. coli was used as the negative control. This result confirms that strain $\mathrm{CSK}_{1}{ }^{\mathrm{T}}$ should be separated into a different species from its closest relative, $C$. thermocellum. The $\mathrm{G}+\mathrm{C}$ content of the DNA of strain $\mathrm{CSK}^{\mathrm{T}}$ was $41 \cdot 3 \mathrm{~mol} \%$.

Strain $\mathrm{CSK} 1^{\mathrm{T}}$ differs from its close relatives, C. thermocellum and C. aldrichii, in terms of optimum temperature for growth. The optimum temperature for growth of strain $\mathrm{CSK}^{\mathrm{T}}$ was $50-55^{\circ} \mathrm{C}$. In contrast, the optimum temperatures for growth of $C$. thermocellum and that of $C$. aldrichii were reported to be $60-64{ }^{\circ} \mathrm{C}$ and $35^{\circ} \mathrm{C}$, respectively $(\mathrm{Ng}$ et al., 1977; Yang et al., 1990). Strain CSK1 $1^{\mathrm{T}}$ did not grow or degrade cellulose at temperatures under $45^{\circ} \mathrm{C}$, and scarcely grew at $60^{\circ} \mathrm{C}$. The bacterial community from which strain $\mathrm{CSK}^{\mathrm{T}}$ was isolated was cultivated at $50^{\circ} \mathrm{C}$, and the optimum temperature for cellulose degradation was between 50 and $55^{\circ} \mathrm{C}$ (Haruta et al., 2002). This temperature sensitivity could be one of the reasons why only strain $\mathrm{CSK} 1^{\mathrm{T}}$ survived within the bacterial community as a cellulolytic bacterium at $50^{\circ} \mathrm{C}$.

Strain $\mathrm{CSK}^{\mathrm{T}}$ also differs from its closest relative, $C$. 


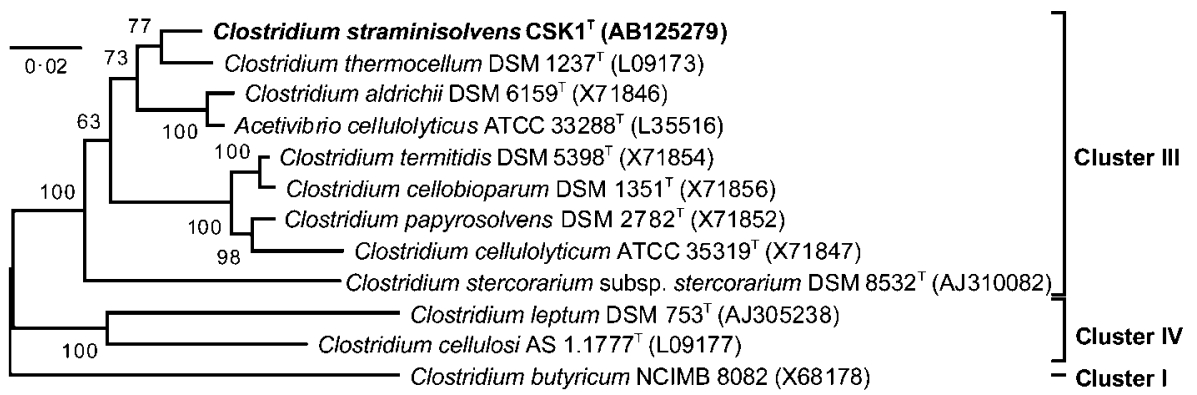

Fig. 2. Phylogenetic dendrogram indicating the position of strain $\mathrm{CSK} 1^{\top}$ amongst cluster III of the order Clostridiales and related bacteria, based on $16 \mathrm{~S}$ rRNA gene sequence data. Bootstrap values are given at the branching points. Accession numbers are shown in parentheses. Bar, $2 \%$ sequence divergence.

thermocellum, in that it has a higher tolerance of $\mathrm{O}_{2}$. Strain $\mathrm{CSK} 1^{\mathrm{T}}$ grew in an atmosphere containing an $\mathrm{O}_{2}$ concentration of up to $4 \%$. In contrast, C. thermocellum (IAM $13660^{\mathrm{T}}$ ) could not grow in an atmosphere containing an $\mathrm{O}_{2}$ concentration of more than $2 \%$. In the genus Clostridium, some species that can grow in an atmosphere containing an $\mathrm{O}_{2}$ concentration of up to $6 \%$ have been reported, and the species have the ability to consume $\mathrm{O}_{2}$ (Küsel et al., 2001; Karnholz et al., 2002). Colour changing of resazurin in the media indicated that strain $\mathrm{CSK}^{\mathrm{T}}$ consumes $\mathrm{O}_{2}$ during cultivation in an atmosphere containing $\mathrm{O}_{2}$. Cellulolytic clostridia with aerotolerance have not been reported previously. This aerotolerance of strain $\mathrm{CSK}^{\mathrm{T}}$ could be advantageous to its survival within the bacterial community cultivated under static conditions that were not strictly anaerobic.

\section{Description of Clostridium straminisolvens sp. nov.}

Clostridium straminisolvens (stra.mi.ni.sol'vens. L. neut. n. stramen straw; L. v. solvere to dissolve; N.L. part. adj. straminisolvens straw-dissolving).

Cells are anaerobic, non-motile, spore-forming, straight or slightly curved rods, $0 \cdot 5-1 \cdot 0 \mu \mathrm{m}$ wide and $3 \cdot 0-8 \cdot 0 \mu \mathrm{m}$ long, occurring singly or in pairs. The optimum temperature for growth is $50-55^{\circ} \mathrm{C}$, and no growth occurs at or below $45^{\circ} \mathrm{C}$ or at $65^{\circ} \mathrm{C}$ and above. The optimum initial $\mathrm{pH}$ for growth is $7 \cdot 5$, and growth occurs between $\mathrm{pH} 6 \cdot 0$ and $8 \cdot 5$. Growth occurs under a gas phase containing up to $4 \% \mathrm{O}_{2}$. Cellulose and cellobiose are utilized as sole carbon and energy sources; the fermentation products are acetate, lactate, ethanol, hydrogen and carbon dioxide. Glucose, fructose, ribose, mannose, mannitol, melibiose, saccharose, xylose, sucrose, lactose, xylan and starch were not utilized as sole carbon and energy sources. The $\mathrm{G}+\mathrm{C}$ content of the DNA of the type strain is $41 \cdot 3 \mathrm{~mol} \%$ (HPLC).

The type strain, $\mathrm{CSK}^{\mathrm{T}}\left(=\mathrm{DSM} 16021^{\mathrm{T}}=\mathrm{IAM} 15070^{\mathrm{T}}\right)$, was isolated from a cellulose-degrading bacterial community.

\section{References}

Altschul, S. F., Madden, T. L., Schaffer, A. A., Zhang, J., Zhang, Z., Miller, W. \& Lipman, D. J. (1997). Gapped BLAST and PSI-BLAST: a new generation of protein database search programs. Nucleic Acids Res 25, 3389-3402.

Collins, M. D., Lawson, P. A., Willems, A., Cordoba, J. J., Fernandez-Garayzabal, J., Garcia, P., Cai, J., Hippe, H. \& Farrow, J. A. E. (1994). The phylogeny of the genus Clostridium: proposal of five new genera and eleven new species combinations. Int J Syst Bacteriol 44, 812-826.

Coughlan, M. P. \& Mayer, F. (1992). The cellulose-decomposing bacteria and their enzyme systems. In The Prokaryotes, 2nd edn, pp. 460-516. Edited by A. Balows, H. G. Trüper, M. Dworkin, W. Harder \& K. H. Schleifer. New York: Springer.

Devereux, R. \& Willis, S. G. (1995). Amplification of ribosomal RNA sequences. In Molecular Microbial Ecology Manual, 3.3.1, pp. 1-11. Edited by A. D. L. Akkermans, J. D. van Elsas \& F. J. de Bruijn. Dordrecht: Kluwer.

Drent, W. J., Lahpor, G. A., Wiegant, W. M. \& Gottschal, J. C. (1991). Fermentation of inulin by Clostridium thermosuccinogenes sp. nov., a thermophilic anaerobic bacterium isolated from various habitats. Appl Environ Microbiol 57, 455-462.

Ezaki, T., Hashimoto, Y. \& Yabuuchi, E. (1989). Fluorometric deoxyribonucleic acid-deoxyribonucleic acid hybridization in microdilution wells as an alternative to membrane filter hybridization in which radioisotopes are used to determine genetic relatedness among bacterial strains. Int J Syst Bacteriol 39, 224-229.

Felsenstein, J. (1985). Confidence limits on phylogenies: an approach using the bootstrap. Evolution 39, 783-791.

Fukumori, F., Kudo, T., Sashihara, N., Nagata, Y., Ito, K. \& Horikoshi, K. (1989). The third cellulase of alkalophilic Bacillus sp. strain N-4: evolutionary relationships within the cel gene family. Gene 76, 289-298.

Haruta, S., Cui, Z., Huang, Z., Li, M., Ishii, M. \& Igarashi, Y. (2002). Construction of a stable microbial community with high cellulosedegradation ability. Appl Microbiol Biotechnol 59, 529-534.

Hayashi, H., Takehara, M., Hattori, T., Kimura, T., Karita, S., Sakka, K. \& Ohmiya, K. (1999). Nucleotide sequences of two contiguous and highly homologous xylanase genes $x y n \mathrm{~A}$ and $x y n \mathrm{~B}$ and characterization of XynA from Clostridium thermocellum. Appl Microbiol Biotechnol 51, 348-357.

Heijthuijsen, J. H. F. G. \& Hansen, T. A. (1986). Interspecies hydrogen transfer in co-cultures of methanol-utilizing acidogens and 
sulphate-reducing or methanogenic bacteria. FEMS Microbiol Ecol 7, 387-429.

Holdeman, L. V., Cato, E. P. \& Moore, W. E. C. (1977). Anaerobe Laboratory Manual, 4th edn. Blacksburg, VA: Anaerobe Laboratory, Virginia Polytechnic Institute and State University.

Karnholz, A., Küsel, K., Gößner, A., Schramm, A. \& Drake, H. L. (2002). Tolerance and metabolic response of acetogenic bacteria toward oxygen. Appl Environ Microbiol 68, 1005-1009.

Kumar, S., Tamura, K., Jakobsen, I. B. \& Nei, M. (2001). MEGA2: molecular evolutionary genetics analysis software. Bioinformatics 17, 1244-1245.

Küsel, K. \& Drake, H. L. (1995). Effects of environmental parameters on the formation and turnover of acetate by forest soils. Appl Environ Microbiol 61, 3667-3675.

Küsel, K., Karnholz, A., Trinkwalter, T., Devereux, R., Acker, G. \& Drake, H. L. (2001). Physiological ecology of Clostridium glycolicum $\mathrm{RD}-1$, an aerotolerant acetogen isolated from sea grass roots. Appl Environ Microbiol 67, 4734-4741.

Lewis, S. M., Montgomery, L., Garleb, K. A., Berger, L. L. \& Fahey, G. C., Jr (1988). Effects of alkaline hydrogen peroxide treatment on in vitro degradation of cellulosic substrates by mixed ruminal microorganisms and Bacteroides succinogenes S85. Appl Environ Microbiol 54, 1163-1169.

Mesbah, M., Premachandran, U. \& Whitman, W. B. (1989). Precise measurement of the $\mathrm{G}+\mathrm{C}$ content of deoxyribonucleic acid by high-performance liquid chromatography. Int J Syst Bacteriol 39, 159-167.
Ng, T. K., Weimer, P. J. \& Zeikus, J. G. (1977). Cellulolytic and physiological properties of Clostridium thermocellum. Arch Microbiol 114, 1-7.

Odom, J. M. \& Wall, J. D. (1983). Photoreduction of $\mathrm{H}_{2}$ from cellulose by an anaerobic bacterial coculture. Appl Environ Microbiol 45, 1300-1395.

Saddler, J. N. \& Chan, M. K. H. (1982). Optimization of Clostridium thermocellum growth on cellulose and pretreated wood substrates. Appl Microbiol Biotechnol 16, 99-104.

Saitou, N. \& Nei, M. (1987). The neighbor-joining method: a new method for reconstructing phylogenetic trees. Mol Biol Evol 4, 406-425.

Taillisz, P., Girard, H., Millet, J. \& Beguin, P. (1989). Enhanced cellulose fermentation by an asporogenous and ethanol-tolerant mutant of Clostridium thermocellum. Appl Environ Microbiol 55, 207-211.

Tanaka, K., Ding, M. Y., Helaleh, M. I. H. \& 7 other authors (2002). Vacancy ion-exclusion chromatography of carboxylic acids on a weakly acidic cation-exchange resin. J Chromatogr A 956, 209-214.

Thompson, J. D., Gibson, T. J., Plewniak, F., Jeanmougin, F. \& Higgins, D. G. (1997). The CLUSTAL_X Windows interface: flexible strategies for multiple sequence alignment aided by quality analysis tools. Nucleic Acids Res 25, 4876-4882.

Yang, J. C., Chynoweth, D. P., Williams, D. S. \& Li, A. (1990). Clostridium aldrichii sp. nov., a cellulolytic mesophile inhabiting a wood-fermenting anaerobic digester. Int J Syst Bacteriol 40, 268-272.

Zhu, H., Qu, F. \& Zhu, L. H. (1993). Isolation of genomic DNAs from plants, fungi and bacteria using benzyl chloride. Nucleic Acids Res 21, 5279-5280. 